\title{
Spontaneous abortions and congenital malformations among women exposed to tetrachloroethylene in dry cleaning
}

\author{
PENTTI KYYRÖNEN, ${ }^{1}$ HELENA TASKINEN, ${ }^{1}$ MARJA-LIISA LINDBOHM, ${ }^{1}$ KARI \\ HEMMINKI, ${ }^{1}$ AND OLLI P HEINONEN ${ }^{2}$ \\ From ${ }^{1}$ the Institute of Occupational Health, Helsinki; ${ }^{2}$ National Public Health Institute, Helsinki, Finland.
}

\section{ABSTRACT}

Study objective: The aim of the study was to determine whether exposure to tetrachloroethylene during the first trimester of pregnancy has harmful effects on pregnancy outcome.

Design: The study used record linkage identification of cases and case-control comparison.

Setting: The study involved dry cleaner and laundry workers throughout Finland who had become pregnant during the study period. Controls were age matched but otherwise unselected women giving birth to normal babies in the study period.

Subjects: Cases were defined as women who had been treated for spontaneous abortion or had delivered a malformed child. Out of 5700 workers nearly half had been pregnant during the study? period. One pregnancy only was randomly selected for study per worker, and the final study尺 population was 247 women with spontaneous abortions and 33 with malformed infants. Three age matched controls were selected for each abortion case and five for each malformation case.

Measurements and main results: Three women out of four had worked in early pregnancy. Exposure information was collected from 1108 women by mailed questionnaires, with a $77 \%$ response, and was partly confirmed by biological monitoring data. Exposure to tetrachloroethylene was found to be significantly associated with spontaneous abortions (odds ratio $3 \cdot 6, \mathrm{p}<0.05$ ).

Conclusion: The findings, together with other available data, indicate that exposure of pregnant women to tetrachloroethylene needs to be minimised.

In industry it is common for workers to be exposed to multiple chemicals, eg, to mixtures of solvents. In a Finnish study among the female members of the Union of Chemical Workers a significantly increased risk of spontaneous abortions has been found. One tenth of the study population included laundry and dry cleaning workers. ${ }^{1}$ Identification of a single harmful agent in the working environment is usually difficult, but in dry cleaning work the exposure is mainly to tetrachloroethylene. Therefore the laundry and dry cleaning industry was chosen as the source population for this study, in which we studied the effects of tetrachloroethylene on spontaneous abortions and congenital malformations.

\section{Methods}

Steps of the study were (1) identification of the female dry cleaning and laundry workers, (2) location of their pregnancies in the health registers, (3) selection of cases of spontaneous abortion or malformation, and control cases, and (4) acquisition of the exposure information by mailed questionnaires supplemented by biological monitoring data when available (figure).

The study population was collected from the registers of the Union of Chemical Workers and of the Municipal Workers' Union of Finland for the period 1973-1983. Workers who had resigned from the Unions during the study period were included, except those who had resigned from the Chemical Workers Union between 1973 and 1977. Since not all laundry and dry cleaning workers are union members, every employer of dry cleaning and laundry staff in the country was mailed a questionnaire requesting information on female personnel employed for at least three months during the 1973-1983 period. The employers were asked whether dry cleaning chemicals were used and which workers had participated in the dry cleaning process. 


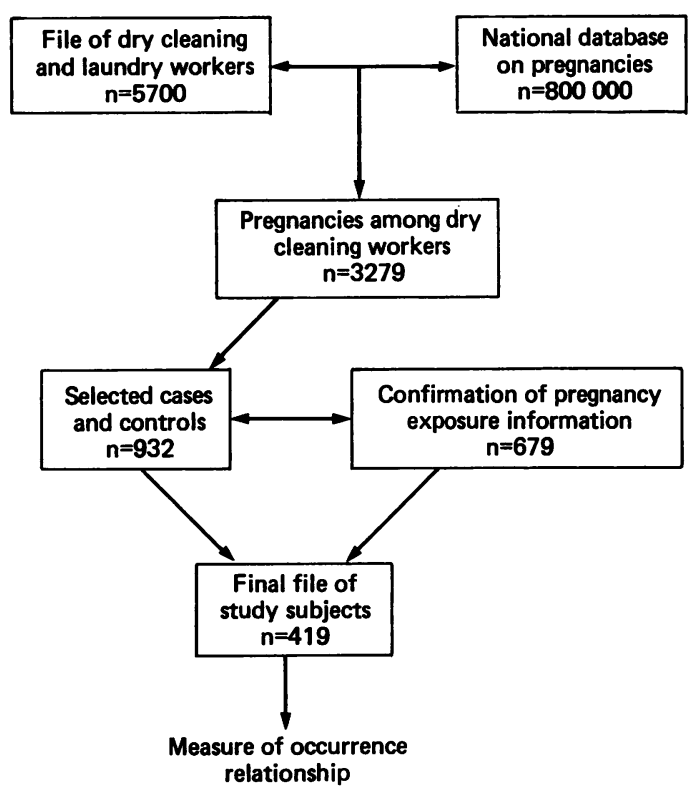

Figure The strategy and population numbers in the study on spontaneous abortions among women in dry cleaners and laundries.

Data on the pregnancies were obtained by linking the file on the study subjects with the nationwide Hospital Discharge Register, supplemented with data on patients treated in clinics and the Finnish Register of Congenital Malformations. The total number of women who had worked in dry cleaning or laundry during the 11 year study period was $\mathbf{5 7 0 0}$. According to the registers they had had 3279 pregnancies (2367 births, 306 spontaneous abortions and 606 induced abortions) during the period. Only one pregnancy per woman was randomly selected for the data analyses, giving 247 dry cleaning and laundry workers with spontaneous abortions and 33 with malformed infants. The number of women who had given birth to a healthy child, and who had not had a spontaneous abortion or given birth to a malformed child, was 1385. Descriptions on the coverage and reliability of the registers have been published. ${ }^{2} 3$

The study continued according to a case-control design. The women who had been discharged from hospitals or treated at clinics for spontaneous abortion (ICD-8 codes 643 and 645) between 1973 and 1983 were defined as cases. In a mail survey 14 women reported a spontaneous abortion which was not included in the Register data base. These were also treated as index cases of spontaneous abortion in the analyses. In the other part of the study dealing with birth defects the woman was defined as a case if she had given birth to a malformed child. Nine women who reported a birth of a malformed child between 1973 and 1983 and who were not included in the Malformation Register were considered as index cases. The diagnosis and description of the type of malformation was checked by a specialist. Subluxations of the hip (ICD-8 code 755.6) were excluded. Three age matched controls in the spontaneous abortion study and five in the malformation study were selected for each case from the women who had given birth to a healthy child (nearest available matching of age with tolerance of \pm 2 years).

Questionnaires requesting information about general work tasks (dry cleaning, pressing, ironing, spot removing, dyeing, heavy lifting), specific exposure to tetrachloroethylene, trichloroethylene, fluorocarbons and other chemicals, temperature of the work room, personal habits (smoking, alcohol use), pregnancy history, health status and febrile diseases during the first 3 months of the pregnancy were mailed to the study subjects.

The questionnaire was mailed to 923 subjects in the spontaneous abortion study (243 cases and 680 controls) and to 185 subjects in the malformation study (32 cases and 153 controls). After four mailings the response rate was $77.2 \%$ in the spontaneous abortion study and $81 \cdot 1 \%$ in the malformation study. The response rate was less for index cases than for controls: spontaneous abortion $68.3 \%$, malformations $75.0 \% v 80.4 \%$ and $82.4 \%$ respectively in the controls. A considerable proportion of the spontaneous abortion cases $(25.9 \%)$ did not report the study pregnancy found in the register. Seven of them reported the exposures and other information from the year of the pregnancy and were included in the analyses. Altogether 679 study subjects met the criteria for reporting the study pregnancy and the corresponding exposures. Further loss of material was due to the individual matching, since all the controls with a missing case were removed. The final material consisted of 130 cases of spontaneous abortion and 289 controls (figure). There were 24 cases of malformation and 93 controls.

The reported exposure to tetrachloroethylene was assessed as high when (1) the work tasks included dry cleaning for at least one hour daily on average, or (2) the women reported handling of tetrachloroethylene at least once a week. The criteria of low exposure were: (1) the work tasks included pressing at a dry cleaners' or spot removing, (2) the woman reported handling of tetrachloroethylene less than once a week.

Reported alcohol use and heavy lifting were scored according to the predetermined rules. Scores for alcohol use were determined by the separate frequencies of use of spirits, wine and beer; daily 
use $=7$ points; $3-6$ times per week $=4.5$ points; $1-2$ times per week $=1.5$ points; less than once a week $=0.5$ points; none $=0$ points. If the sum of the scores was 1.5 points or more, alcohol use was classified as "frequent". The rules for scoring daily heavy lifting were as follows: loads weighing over $20 \mathrm{~kg}=5$ points per lift; loads weighing $10-19 \mathrm{~kg}=3$ points per lift; loads weighing $5-9 \mathrm{~kg}=1$ point per lift. Heavy lifting was classified as "frequent" if the sum of the scores exceeded 30 points.

The logistic regression model for individually matched data, based on the conditional likelihood, was adopted in analysis of both studies. ${ }^{4}$ The statistical significance was evaluated by comparing the standardised parameter estimates with the normal distribution.

\section{Results}

High exposure to tetrachloroethylene during early pregnancy seemed to be associated with spontaneous abortions. For seven study subjects biological monitoring results based on blood tetrachloroethylene measurements (B-TCE) from the same work were available. With one exception all measurements had been conducted within 1-10 months from the first trimester of the study pregnancy. The workers' reporting of their exposure agreed well with the results of the measurements (table 1). The number of cases of spontaneous abortion (130) and controls (289) exposed to different agents and other relevant factors are given in table 2.

Table 1 Comparison of blood tetrachloroethylene (B-TCE) measurements and the women's reports of their exposure in dry cleaning.

\section{Reported}

Measurement

Subjects B-TCE (umol/litre) ${ }^{a}$ TCE exposure Dry cleaning work

\begin{tabular}{llll}
\hline Cases & & & \\
1 & $2 \cdot 6 ;{ }^{2 \cdot 2}$ & yes & yes \\
2 & $0 \cdot 1^{b}$ & yes, seldom & no \\
3 & $0 \cdot 3$ & yes & yes \\
4 & $0 \cdot 6 ; 1 \cdot 1$ & yes & yes \\
Controls & $3 \cdot 6$ & & \\
1 & 0.5 & yes & yes \\
2 & 0.5 & no & no; pressing \\
3 & 0.3 & yes, seldom & no; packing
\end{tabular}

${ }^{a}$ Measurements 1-10 months before or after the first trimester of pregnancy. Values for the non-exposed are generally less than $0 \cdot 1$ $\mu \mathrm{mol} / \mathrm{litre}$.

${ }^{b}$ Measurements 5 years after the study pregnancy.

In the univariate logistic analysis for chemical exposures and spontaneous abortion, an increased odds ratio (OR) was found for high
Table 2 Risk indicators among cases of spontaneous abortions and their controls.

\begin{tabular}{|c|c|c|c|c|}
\hline \multirow[t]{2}{*}{ Indicator } & \multicolumn{2}{|c|}{ Cases } & \multicolumn{2}{|c|}{ Controls } \\
\hline & $n$ & $\%$ & $n$ & $\%$ \\
\hline $\begin{array}{l}\text { A. Worked during pregnancy } \\
\text { B. Worked in a dry cleaners } \\
\text { C. Worked in a laundry } \\
\text { a }\end{array}$ & $\begin{array}{r}101 \\
39 \\
18\end{array}$ & $\begin{array}{l}77 \cdot 7 \\
38 \cdot 6 \\
17 \cdot 8\end{array}$ & $\begin{array}{r}208 \\
69 \\
24\end{array}$ & $\begin{array}{l}72 \cdot 0 \\
33 \cdot 2 \\
11 \cdot 6\end{array}$ \\
\hline $\begin{array}{l}\text { High exposure to } \\
\text { tetrachloroethylene }{ }^{\mathrm{b}} \\
\text { work tasks included dry cleaning } \\
\text { frequent handling of } \\
\text { tetrachloroethylene }\end{array}$ & $\begin{array}{r}9 \\
7 \\
7\end{array}$ & $\begin{array}{c}23 \cdot 1 \\
17 \cdot 9 \\
\\
17 \cdot 9\end{array}$ & $\begin{array}{l}6 \\
3\end{array}$ & $\begin{array}{l}8.7 \\
4.3 \\
\\
8.7\end{array}$ \\
\hline $\begin{array}{l}\text { Low exposure to } \\
\text { tetrachloroethylene }\end{array}$ & 8 & 20.5 & 23 & $33 \cdot 3$ \\
\hline Exposure to other solvents ${ }^{\mathrm{a}}$ & 6 & 5.9 & 6 & $2 \cdot 9$ \\
\hline $\begin{array}{l}\text { Heavy lifting at work } \\
\text { frequently }^{\mathrm{a}} \\
\text { seldom }^{\mathrm{a}}\end{array}$ & $\begin{array}{l}31 \\
28\end{array}$ & $\begin{array}{l}30 \cdot 7 \\
27 \cdot 7\end{array}$ & $\begin{array}{l}45 \\
60\end{array}$ & $\begin{array}{l}21 \cdot 6 \\
28 \cdot 8\end{array}$ \\
\hline $\begin{array}{l}\text { Temperature of the } \\
\text { work place } \geq 24^{\circ} \mathrm{C}^{\mathrm{a}}\end{array}$ & 38 & $37 \cdot 6$ & 68 & 32.7 \\
\hline $\begin{array}{l}\text { Use of alcohol } \\
\text { frequent } \\
\text { seldom }\end{array}$ & $\begin{array}{l}15 \\
29\end{array}$ & $\begin{array}{l}12 \cdot 5 \\
24 \cdot 2\end{array}$ & $\begin{array}{l}18 \\
69\end{array}$ & $\begin{array}{r}6 \cdot 4 \\
24 \cdot 6\end{array}$ \\
\hline Smoking & 46 & $37 \cdot 1$ & 107 & $36 \cdot 2$ \\
\hline Nulliparity & 60 & $46 \cdot 2$ & 123 & $42 \cdot 6$ \\
\hline Febrile disease & 13 & $10 \cdot 0$ & 34 & $11 \cdot 8$ \\
\hline
\end{tabular}

tetrachloroethylene exposure $(\mathrm{OR}=3 \cdot 6$; table 3). The. odds ratios, separately, for the two high exposure factors assessed (dry cleaning work and handling of tetrachloroethylene) were 4.9 and 3.0 , respectively. The odds ratios were also above unity, though not reaching statistical significance, for handling of solvents other than tetrachloroethylene $(\mathrm{OR}=2 \cdot 2)$. The other solvents were petroleum benzine, toluene, acetone, thinner, and spot remover mixtures. The odds ratio for moderate or frequent alcohol use was also increased $(O R=2 \cdot 1)$. Further analysis of factors with odds ratios less than 1.5 was omitted. Such factors were: working during pregnancy $(\mathrm{OR}=0.9)$, working at a dry cleaners $(O R=1 \cdot 3)$, low exposure to tetrachloroethylene $(\mathrm{OR}=0.7)$, seldom use of alcohol $(\mathrm{OR}=1 \cdot 1)$, smoking $(\mathrm{OR}=1 \cdot 0)$, warmness of the workplace $(\mathrm{OR}=1 \cdot 2)$, febrile disease $(\mathrm{OR}=0.8)$, and nulliparity $(\mathrm{OR}=0.9)$.

In the multivariate logistic analysis for the remaining factors and abortion the odds ratio for high exposure to tetrachloroethylene was 3.4 . The odds ratios also deviated from unity, with borderline statistical significance, for frequent alcohol use and frequent heavy lifting at work (table 4).

In the part of the study dealing with congenital malformations there were 24 cases and 93 controls. Their exposure status and other relevant factors are 
Table 3 Effects of individual exposures of spontaneous abortion based on univariate matched logistic regression analysis.

\begin{tabular}{lll}
\hline $\begin{array}{l}\text { Exposure } \\
\text { (first trimester) }\end{array}$ & Odds ratio & $95 \%$ Confidence interval \\
\hline $\begin{array}{l}\text { High exposure to } \\
\text { tetrachloroethylene }\end{array}$ & 3.6 & $1 \cdot 3-11 \cdot 2^{*}$ \\
$\begin{array}{l}\text { Frequent handling of } \\
\text { tetrachloroethylene }\end{array}$ & 3.0 & $0.9-9 \cdot 6$ \\
$\begin{array}{l}\text { Dry cleaning work } \\
\text { Exposure to } \\
\text { other solvents }\end{array}$ & 4.9 & $1 \cdot 3-19 \cdot 5^{*}$ \\
$\begin{array}{l}\text { Use of alcohol } \\
\text { frequent }\end{array}$ & 2.2 & $0.7-7 \cdot 5$ \\
$\quad$ seldom & 2.1 & $1 \cdot 0-4 \cdot 3^{*}$ \\
Smoking & 1.1 & $0.7-1 \cdot 8$ \\
\hline
\end{tabular}

${ }^{*} \mathrm{p}<0.05$

Table 4 Adjusted effects of exposures on spontaneous abortion, based on multivariate logistic regression analysis.

\begin{tabular}{lll}
$\begin{array}{l}\text { Exposure } \\
\text { (first trimester) }\end{array}$ & Odds ratio & $95 \%$ Confidence interval \\
\hline $\begin{array}{l}\text { High exposure to } \\
\text { tetrachloroethylene }\end{array}$ & 3.4 & $1.0-11 \cdot 2^{*}$ \\
$\begin{array}{l}\text { Frequent use of solvents } \\
\text { other than } \\
\text { tetrachloroethylene }\end{array}$ & 1.5 & $0.4-5.4$ \\
$\begin{array}{l}\text { Frequent heavy lifting } \\
\text { at work }\end{array}$ & 1.9 & $1.0-2.8$ \\
Frequent use of alcohol & 2.0 & $1.0-4.0$ \\
\hline
\end{tabular}

${ }^{*} \mathrm{p}<0.05$

given in table 5. Univariate analysis (table 6) showed an odds ratio of 5.9 for exposure to solvents other than tetrachloroethylene. These were spot removers (two cases and one control exposed), acetone (one case) and thinner (one control). The odds ratio was also significantly increased for febrile disease during early pregnancy $(O R=6 \cdot 3)$. Multivariate analysis was not done because of the small numbers.

\section{Discussion}

The results of this study suggest that high exposure to tetrachloroethylene in dry cleaners during pregnancy increases the risk for spontaneous abortions. Exposure to solvents other than tetrachloroethylene showed an increased odds ratio for congenital malformations, as did febrile diseases, but the small numbers do not justify any firm conclusions.

Epidemiological studies on occupational exposures and reproductive outcomes are sensitive to bias if the exposure status influences the reporting of outcome. In this study the information on the pregnancy
Table 5 Risk indicators among cases of congenital malformations and their controls.

\begin{tabular}{|c|c|c|c|c|}
\hline \multirow[b]{2}{*}{ Indicator } & \multicolumn{2}{|c|}{ Cases } & \multicolumn{2}{|c|}{ Controls } \\
\hline & $n$ & $\%$ & $n$ & $\%$ \\
\hline $\begin{array}{l}\text { A. Worked during pregnancy } \\
\text { B. Worked in a dry cleaners } \\
\text { C. Worked in a laundry }\end{array}$ & $\begin{array}{r}20 \\
4 \\
1\end{array}$ & $\begin{array}{r}83 \cdot 3 \\
25 \cdot 0 \\
5 \cdot 0\end{array}$ & $\begin{array}{l}65 \\
22 \\
11\end{array}$ & $\begin{array}{l}70 \cdot 0 \\
33 \cdot 8 \\
16 \cdot 7\end{array}$ \\
\hline $\begin{array}{l}\text { Tetracholorethylene } \\
\text { high exposureb } \\
\text { low exposure }\end{array}$ & $\begin{array}{l}0 \\
2\end{array}$ & $\begin{array}{r}0.0 \\
50 \cdot 0\end{array}$ & $\begin{array}{l}1 \\
8\end{array}$ & $\begin{array}{r}4 \cdot 5 \\
36 \cdot 4\end{array}$ \\
\hline Exposure to other solvents ${ }^{\mathrm{a}}$ & 3 & $15 \cdot 0$ & 2 & $3 \cdot 1$ \\
\hline $\begin{array}{l}\text { Heavy lifting at work } \\
\text { frequently } \\
\text { seldom }^{\mathrm{a}}\end{array}$ & $\begin{array}{l}3 \\
3\end{array}$ & $\begin{array}{l}15.0 \\
15.0\end{array}$ & $\begin{array}{l}20 \\
11\end{array}$ & $\begin{array}{l}29 \cdot 4 \\
16 \cdot 2\end{array}$ \\
\hline $\begin{array}{l}\text { Temperature of the } \\
\text { work place } \geq 24^{\circ} \mathrm{C}^{\mathrm{a}}\end{array}$ & 6 & $30 \cdot 0$ & 28 & $41 \cdot 2$ \\
\hline $\begin{array}{l}\text { Use of alcohol } \\
\text { frequent } \\
\text { seldom }\end{array}$ & $\begin{array}{r}0 \\
11\end{array}$ & $\begin{array}{r}0.0 \\
45 \cdot 8\end{array}$ & $\begin{array}{r}6 \\
25\end{array}$ & $\begin{array}{r}6 \cdot 5 \\
26 \cdot 9\end{array}$ \\
\hline Smoking & 8 & $33 \cdot 3$ & 38 & $40 \cdot 9$ \\
\hline Nulliparity & 14 & $56 \cdot 0$ & 51 & $54 \cdot 8$ \\
\hline Febrile disease & 6 & $25 \cdot 0$ & 6 & $6 \cdot 5$ \\
\hline
\end{tabular}

aper cent of $A ;{ }^{b}$ per cent of $B$.

Table 6 Effects of individual exposures of congenital malformations based on univariate, matched logistic regression analysis.

\begin{tabular}{lll}
$\begin{array}{l}\text { Exposure } \\
\text { (first trimester) }\end{array}$ & Odds ratio & $95 \%$ Confidence interval \\
\hline $\begin{array}{l}\text { Tetrachloroethylene } \\
\text { (any level) }\end{array}$ & 0.8 & $0.2-3.5$ \\
$\begin{array}{l}\text { Handling of other } \\
\text { solvents (any level) }\end{array}$ & 5.9 & $1.0-35.7^{*}$ \\
$\begin{array}{l}\text { Alcohol use } \\
\text { (any frequency) }\end{array}$ & 1.6 & $0.7-3.8$ \\
Smoking & 0.7 & $0.3-1.9$ \\
Febrile disease & 6.3 & $2.2-17.5 \dagger$ \\
\hline
\end{tabular}

* $\mathrm{p}<0.05 ; \mathrm{tp}<0.01$

outcome was based on objective registers and was to a great extent confirmed by the study subjects. The addition of those cases who did not confirm the registered spontaneous abortion did not change the overall results markedly. Thus, the non-confirmation of spontaneous abortion did not seem to depend selectively on exposure. In our previous studies the confirmation of spontaneous abortions has been better, up to $89 \%$. $^{5}$

In studies concerning spontaneous abortions in general the finding of appropriate controls has been a problem. In this study the source population, from which the cases and controls were retrieved, was very homogeneous; the work tasks and the social class of 
dry cleaning and laundry workers are similar. Thus, the association found between tetrachloroethylene exposure and spontaneous abortions seems to be genuine.

Another potential source of bias is selective participation, if the participation also depends on exposure. In this study women who had suffered from spontaneous abortion or given birth to a malformed child participated less eagerly than the controls. The situation differs from some studies where women with an adverse pregnancy outcome, especially when exposed, have been more eager to participate than those with a normal child. ${ }^{6}$ We were able to evaluate this possible selection on the basis of the information on dry cleaning work obtained from the employers. There were altogether 521 women $(55 \%$ of the total study population) on whom information from the employers was available. Of these 149 (28.6\%) had had a study pregnancy during employment, and eight cases $(19.5 \%)$ and six controls $(5.6 \%)$ were involved in dry cleaning work according to the employer's report, giving a crude odds ratio of $4 \cdot 1$. Two of these cases and one of the controls did not respond to the questionnaire. These two observations suggest that selection bias does not explain the results.

Exposure information collected by questionnaire may also be biased by selective outcome dependent reporting of the exposure. ${ }^{7}$ Women who had a miscarriage may be prone to recall their exposures better than women whose pregnancy was normal. In this study the worker's own report of tetrachloroethylene exposure as well as her work tasks in the dry cleaning process were the criteria for exposure. The women's self reporting of exposure agreed well with the blood tetrachloroethylene measurements (table 1), adding to the credibility of the findings. About 750 female workers were monitored for tetrachloroethylene exposure during $1977-83$ by the Institute of Occupational Health in Finland. Of the blood tetrachloroethylene measurements conducted on the morning at the end of the working week $4 \%$ exceeded $2.5 \mu \mathrm{mol} / \mathrm{litre}$, which was the reference value for exposed workers until 1988. Blood tetrachloroethylene concentrations over $1.0 \mu \mathrm{mol} /$ litre, indicating moderate exposure to tetrachloroethylene, were found in $22 \%$ of the women. Altogether $91 \%$ of the blood tetrachloroethylene values were above the limit for the non-exposed $(0 \cdot 1 \mu \mathrm{mol} /$ litre). This illustrates a real exposure among the dry cleaning workers.

The exposure levels observed in Finland are a little lower than those reported in Belgium, where the mean blood tetrachloroethylene value in 26 dry cleaning workers was $0.4 \mathrm{mg} /$ litre $(2.4 \mu \mathrm{mol} / \mathrm{litre})$ with a range of $0 \cdot 1-0.8 \mathrm{mg} /$ litre. $^{8}$ Lower exposures were reported in an Italian study ${ }^{9}$ where trichloroacetic acid was measured in urine as an indicator of tetrachloroethylene exposure. The exposure was estimated as low to moderate, the mean urine tetrachloroethylene value being $5 \mu \mathrm{g} /$ litre $(0.03 \mu \mathrm{mol} /$ litre), when compared with the recommendations of the American Conference of Governmental Industrial Hygienists.

The Institute of Occupational Health in Finland conducted measurements of tetrachloroethylene in air in some of the largest dry cleaners during 1973-83. The concentrations in the workers' breathing zone varied from 3 to $29 \mathrm{~cm}^{3} / \mathrm{m}^{3}$ in dry cleaning machine operating tasks and from 3 to $19 \mathrm{~cm}^{3} / \mathrm{m}^{3}$ in the general air of the work room. During the cleaning of the button strainer the transient tetrachloroethylene concentration was as high as $100 \mathrm{~cm}^{3} / \mathrm{m}^{3}$. This procedure was done every other day and lasted only for a few minutes. During other short procedures such as emptying or filling the dry cleaning machine, $4-34 \mathrm{~cm}^{3} / \mathrm{m}^{3}$ concentrations of tetrachloroethylene were measured. Results suggest moderate and occasionally high exposure, and are comparable with reports from other countries, where concentrations of around $20 \mathrm{~cm}^{3} / \mathrm{m}^{3}$ have been measured. ${ }^{810}$

Experimentally, exposure to tetrachloroethylene $\left(300 \mathrm{~cm}^{3} / \mathrm{m}^{3}\right)$ during organogenesis increases intrauterine deaths and resorptions in rats and causes growth disturbances in mice. ${ }^{11}$ The animal data support the findings of this study, although the exposure level in animal tests was 3-10 times higher than those encountered in dry cleaners. The mechanism of action is unclear, but in the biotransformation of tetrachloroethylene, cytotoxic and mutagenic intermediates have been identified in animals. ${ }^{12}$

Dry cleaning and the chemicals used in the process have not been studied much from the viewpoint of reproductive effects. In a small study Bosco et al ${ }^{9}$ found more spontaneous abortions and birth defects (8.9\% and $3.9 \%$, respectively) among dry cleaning workers than among housewives $(2 \cdot 2 \%$ and $2 \cdot 3 \%$, respectively), but the differences were not statistically significant. The proportion of abortions of all pregnancies was similar to that observed earlier among working women and housewives. In another study, where the population consisted of workers monitored biologically for organic solvent exposure, the odds ratio of spontaneous abortion was increased (2.7) for high exposure to tetrachloroethylene. The increased risk was seen mainly among dry cleaning workers, but the finding was not statistically significant. ${ }^{13}$

In the current study results on the effects of alcohol use and smoking during early pregnancy were similar to some recent reports: ${ }^{14} 15$ alcohol increases the risk for spontaneous abortion, but smoking does not. The 
reporting of life style factors is perhaps more susceptible to bias than that of occupational exposures. The effect of such bias is likely to dilute the odds ratios towards unity.

Heavy lifting increased the risk of spontaneous abortion in this study, but less markedly than in our earlier study in the pharmaceutical industry. ${ }^{16}$ Reported results on the effects of lifting on spontaneous abortion are somewhat contradictory. The risk was increased in a Canadian study where the effects of solvents on pregnancy were reported, ${ }^{17}$ but not in a Finnish study. ${ }^{13}$ The association of heavy lifting with preterm birth ${ }^{18} 19$ and low birth weight ${ }^{19}$ have been reported. These add to the evidence on reproductive effects of organic solvents. ${ }^{131620}$

In conclusion, tetrachloroethylene exposure during pregnancy was found to be associated with spontaneous abortion. The finding was based on a small group of exposed and affected workers, but since the study was free of major biases, the occupational health services should be alerted to the potential hazardous effects of tetrachloroethylene on reproduction. According to the International Agency for Research on Cancer $^{21}$ there is sufficient evidence for the carcinogenicity of tetrachloroethylene in animals, but the evidence in humans is inadequate. However, the exposure of pregnant women to tetrachloroethylene needs to be minimised according to the principle that the handling of carcinogens during pregnancy should be avoided.

We thank Ms Tarja Nikula for clerical assistance. The study was supported by a grant from the Finnish Work Environment Fund.

Address for correspondence and reprints: Professor K Hemminki, Institute of Occupational Health, Topeliuksenkatu 4laA, SF-00250 Helsinki, Finland.

\section{References}

${ }^{1}$ Hemminki K, Franssila E, Vainio H. Spontaneous abortions among female chemical workers in Finland. Int Arch Occup Environ Health 1980; 45: 123-6.

2 Lindbohm M-L, Hemminki K. Nation-wide data base on medically diagnosed spontaneous abortions in Finland. Int J Epidemiol 1988; 17: 568-73.

${ }^{3}$ Saxén L. Twenty years of study of the etiology of congenital malformations in Finland. In: Kalter $\mathbf{H}$, ed. Issues and reviews in teratology. New York: Plenum 1983: 73-110.

${ }^{4}$ Breslow NE, Day NE. Statistical methods in cancer research: the analysis of case-control studies. Lyon: International Agency for Research on Cancer, 1980.
${ }^{5}$ Selevan SG, Lindbohm M-L, Hornung RW, Hemminki K. A study of occupational exposure to antineoplastic drugs and fetal loss in nurses. $N$ Engl J Med 1985; 313: 1173-8.

${ }^{6}$ Axelsson G, Rylander R. Exposure to anaesthetic gases and spontaneous abortion: response bias in a postal questionnaire study. Int J Epidemiol 1982; 11: 250-6.

${ }^{7}$ Hemminki K, Axelson O, Niemi M-L, Ahlborg G. Assessment of methods and results of reproductive occupational epidemiology: spontaneous abortions and malformations in the offspring of working women. Am J Ind Med 1983; 4: 293-307.

${ }^{8}$ Lauwerys R, Herbrand J, Buchet JP, Bernard A, Gaussin J. Health surveillance of workers exposed to tetrachloroethylene in dry-cleaning shops. Int Arch Occup Environ Health 1983; 52: 19-77.

9 Bosco MG, Figà-Talamanca I, Salerno S. Health and reproductive status of female workers in dry cleaning shops. Int Arch Occup Environ Health 1987; 59: 295-301.

${ }^{10}$ Ludwig HR, Meister MV, Roberts DR, Cox C. Worker exposure to perchloroethylene in the commercial dry cleaning industry. Am J Hyg Assoc 1983; 44: 600-5.

${ }^{11}$ Schwetz BA, Leong BMJ, Gehring BJ. The effect of maternally inhaled trichloroethylene, perchloroethylene, methyl chloroform and methylene chloride on embryonal and fetal development in mice and rats. Toxicol Appl Pharmacol 1975; 32: 84-96.

12 Dekant W. Metabolic conversion of tri- and tetrachloroethylene: formation and deactivation of genotoxic intermediates. In: Chambers PL, Gehring P, Sakai $\mathrm{F}$, eds. New concepts and developments in toxicology. (Developments in toxicology and environmental science, Vol 12.) Amsterdam: Elsevier, 1986: $211-21$.

${ }^{13}$ Lindbohm M-L, Taskinen H, Sallmén M, Hemminki K. Spontaneous abortions among women exposed to organic solvents. Paper presented at the XI meeting of the International Epidemiological Association, Helsinki 1987.

${ }^{14}$ Kline J, Stein Z, Susser M, et al. Environmental influences on early reproductive loss in a current New York city study. In: Porter IA, Hook EB, eds. Human embryonic and fetal loss. New York: Academic Press, 1980: 225-40.

${ }^{15}$ Anokute CC. Epidemiology of spontaneous abortions: the effects of alcohol consumption and cigarette smoking. $J$ Natl Med Assoc 1986; 78: 771-5.

16 Taskinen H, Lindbohm M-L, Hemminki K. Spontaneous abortions among women working in the pharmaceutical industry. Br J Ind Med 1986; 43: 199-205.

${ }^{17}$ McDonald AD, McDonald JC, Armstrong B, et al. Fetal death and work in pregnancy. $\mathrm{Br} J$ Ind Med 1988; 45: 148-57.

${ }^{18}$ Mamelle N, Laumon B, Lazar P. Prematurity and occupational activity during pregnancy. Am J Epidemiol 1984; 119: 309-22.

${ }^{19}$ McDonald AD, McDonald JC, Armstrong B, Cherry NM, Robert $\mathrm{D}$. Prematurity and work in pregnancy. $\mathrm{Br} J$ Ind Med 1988; 45: 56-62.

${ }^{20}$ McDonald JC, Lavoie J, Cote R, McDonald AD. Chemical exposures at work in early pregnancy and congenital defect: a case-referent study. $B r \mathrm{~J}$ Ind $M e d$ 1987; 44: 527-33.

${ }^{21}$ International Agency for Research on Cancer. Overall evaluations of carcinogenicity: An updating of IARC Monographs vol 1 to 42 (IARC monographs supplement 7). Lyon: IARC, 1988: 355-7.

Accepted for publication May 1989 